Hydrology and Earth System Sciences, 9, 81-94, 2005

www.copernicus.org/EGU/hess/hess/9/81/

SRef-ID: $1607-7938 /$ hess/2005-9-81

European Geosciences Union

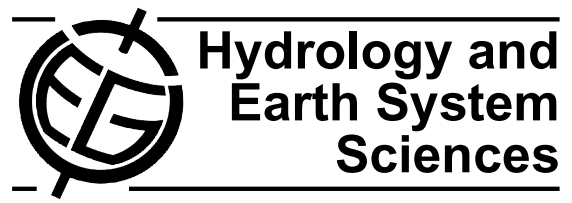

\title{
Faecal sterols as indicators of sewage contamination in estuarine sediments of the Tay Estuary, Scotland: an extended baseline survey
}

\author{
A. D. Reeves and D. Patton
}

Geography Department, University of Dundee, Perth Road, Dundee, DD1 4HN, Scotland, UK

Received: 20 October 2004 - Published in Hydrology and Earth System Sciences Discussions: Revised: 15 May 2005 - Accepted: 1 June 2005 - Published: 16 June 2005

\begin{abstract}
Sterol ratios are used to identify sources, occurrence and partitioning of faecal matter in sediments of the Tay Estuary, Scotland. The $5 \beta /(5 \alpha+5 \beta)$ ratio is used to discriminate between sewage and biogenic sterol sources by comparing the concentrations of coprostanols to cholesterol plus coprostanols. This index shows unambiguous sewage pollution in the Invergowrie Bay area (values $>0.7$ ). The coprostanol/epicoprostanol index is used to differentiate between human and non-human faecal inputs. Ratios confirmed the primary source as human-derived faecal material. The coprostanol/cholesterol ratio was calculated in order to elucidate the contribution of different biogenic sources to the sedimentary sterol budget. Ratios of $>1$ clearly indicate faecal sterol sources. Invergowrie Bay displayed no sterol signature other than sewage. A biogenic source of cholesterol influenced total sterol concentrations upstream of the City of Dundee. Attention is directed to the potential role of density fronts in compartmentalization of faecal material in bottom sediments.
\end{abstract}

\section{Introduction}

Where faecal matter is discharged into a marine system, the sterol "fingerprint" of the source organism is diluted and dispersed. However, the biomarkers of faecal pollution remain distinguishable from other sterols (Galois et al., 1996). By exploiting the differences in the sterol profiles of humans and animals, it is possible to determine the source of the faecal contamination (CSIRO, 2000).

The most abundant faecal sterol, coprostanol, has been detected in the majority of surface waters and sediments contaminated with sewage. Its concentration normally decreases with distance downstream from an isolated point source into the watercourse (Brown and Wade, 1984). Unlike

Correspondence to: A. D. Reeves

(a.d.reeves@dundee.ac.uk) cholesterol, cholestanol, campesterol, $\beta$-sitosterol and stigmastanol, which are present in both sewage and sediments from a variety of sources, coprostanol is not normally present in uncontaminated marine sediments (Walker et al., 1982; Venkatesan and Kaplan, 1990; Green et al., 1992; Green and Nichols, 1995; Elhmalli et al., 1997; Elhmalli et al., 2000). The presence of coprostanol is primarily a consequence of anthropogenic input into a system and hence represents the presence of sewage contamination. Coprostanol can therefore be used to trace polluted sediments (Saliot et al., 1991; Sicre et al., 1994; Walker et al., 1996; Saliot et al., 2002). Its quantification is an effective measure of the degree of sewage contamination (Kelly, 1995). Under anoxic sedimentary conditions, coprostanol will persist and any decline in concentration will be due to physical sediment transport. This persistence has allowed the historical tracing of pollution from the recent past to the late Saxon/early medieval period (Hatcher and McGillivary, 1979; McCalley et al., 1981; Mackenzie et al., 1982; Evershed and Bethell, 1996).

As coprostanol combines with organic colloids it is highly likely to be incorporated into sediments. Elevated coprostanol concentrations are generally associated with sedimentary sequences deposited beneath relatively shallow estuarine waters. This type of depositional environment, rich in sewage-laden materials, is characterised by black streaking of the sediments. Elevated concentrations in deep basins are associated with advected fine-grained sediments, which tend to adsorb to organic carbon (Venkatesan and Kaplan, 1990; Venkatesan et al., 2003). Jeng and Han (1994) showed a $>91 \%$ association between coprostanol and particulates in effluent.

For the detection and quantification of sewage pollution, reliance on the presence of just one sterol, normally coprostanol, may lead to questionable results regarding source contributions to a sediment (Sherblom et al., 1997; Mudge et al., 1999). This study, therefore, examines the presence of four sterols and four stanols. The group comprises

(C) 2005 Author(s). This work is licensed under a Creative Commons License. 
Table 1. Major sterol sources.

\begin{tabular}{|c|c|c|}
\hline Sterol & Major source & Original source \\
\hline Coprostanol & Mammalian faeces & Includes Gonzalez-Vila et al. (1996); Jeng et al. (1996); \\
\hline Epicoprostanol & Mammalian faeces & Mudge and Norris (1997); Mudge and Bebbiano (1997); \\
\hline Cholesterol & Ubiquitous & Leeming and Nichols (1998); Mudge et al. (1999); \\
\hline Cholestanol & Mammalian faeces & O’Leary et al. (1999) \\
\hline Campesterol & Plant matter & Nishimura (1977); Volkman (1986); \\
\hline Stigmasterol & Plant matter & Laurelliard and Saliot (1993); \\
\hline$\beta$-sitosterol & Plant matter & Li et al. (1995); Chan et al. (1998); \\
\hline Stigmastanol & Plant matter & Benfenati et al. (1994) \\
\hline
\end{tabular}

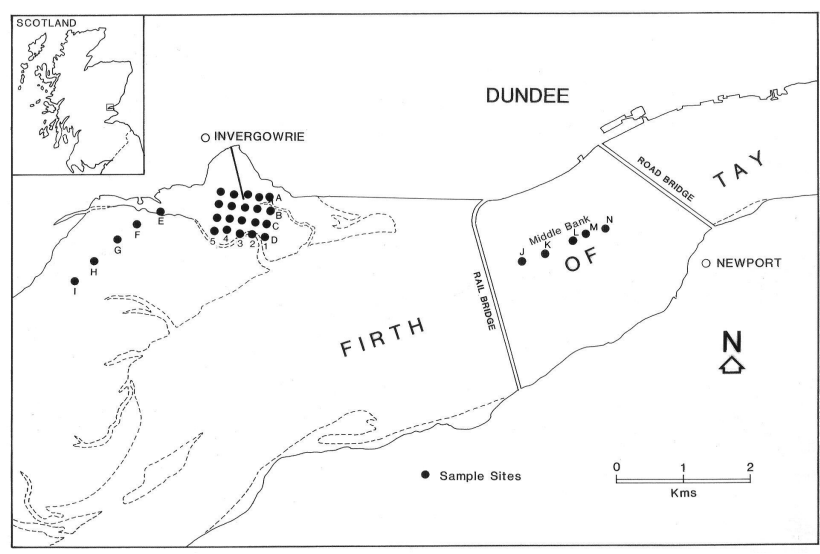

Fig. 1. Tay Estuary: Location and sampling sites.

coprostanol, epicoprostanol and cholestanol, together with cholesterol, campesterol, stigmasterol, $\beta$-sitosterol and stigmastanol, all of which can be detected in sewage and some of which have alternative sources (Table 1).

\section{Geographical area of study}

The Tay catchment (c. $6500 \mathrm{~km}^{2}$ ), represents an area of mixed land use and geology (Buller et al., 1975). The Tay Estuary trends west-east into the North Sea. It is unique in that it is partially developed only on the north shore with no heavy industry discharging into it. Within the estuary boundaries, North Sea water is diluted with freshwater from the Tay and Earn catchments, which contribute more than $95 \%$ of the freshwater input (Cracknell et al., 1987).

The main study area was Invergowrie Bay (UK National Grid: NO 357297) on the north shore of the Tay Estuary (Fig. 1). Within the bay is the terminus of a long outfall, which formerly served the western part of the city of Dundee and the village of Invergowrie. Prior to 1994 the outfall had one of the largest effluent discharge rates in the city $\left(4800 \mathrm{~m}^{3}\right.$ per day; Ferrier and Anderson, 1996) and discharged slightly below the low water mark. This outfall was active at the time of sampling but is no longer used continuously (see below). The sample sites were located away from the main channel, inundated at each high tide and exposed at each low tide.

The Invergowrie Bay long outfall is maintained by Scottish Water. In 1994, Burnside Road pumping station was commissioned to pump wastewater along Riverside Drive to the screening station adjacent to Dundee airport, which was in use up until the commissioning of the Hatton Private Finance Initiative scheme in 2001. Before this scheme, every day nearly 13 million gallons of untreated or partially treated sewage was directly discharging to the Tay Estuary and Angus coastline (North of Dundee). The new scheme is providing full biological treatment for the sewage effluent and approximately 8 million gallons of storage for storm sewage before any discharge takes place at the pumping stations.

From 1994 onwards, the outfalls in this region have been used only in times of heavy rainfall i.e., Combined Sewer Overflow (CSO), with the discharge of screened dilute wastewater into the bay. Effectively nothing has changed since 1994 in terms of the study site. The Invergowrie Bay outfall at Burnside Road still operates as a CSO during storm conditions but for the majority of the year there are no discharges. Improved screening was installed at the site during 2002. Burnside Road PS is only one of a number of CSOs along the Dundee foreshore (Fig. 2). These are required to provide outlets from the sewerage system during rainfall, as the pumping station systems cannot cope with all rainwater generated via surface runoff, as highlighted by the following comment:

"The coastline from Invergowrie to Arbroath has been plagued for decades with the presence of sewage related debris and intermittently poor microbiological water quality at beaches such as Broughty Ferry, Monifieth and Carnoustie. The [Hatton] project has been modelled and designed to remove all sewage related debris from discharging to the receiving waters under normal conditions. In addition, the beaches at Broughty Ferry and Monifieth should be able to meet at least the mandatory standards contained in the Bathing Waters Directive whilst the designated beaches at 


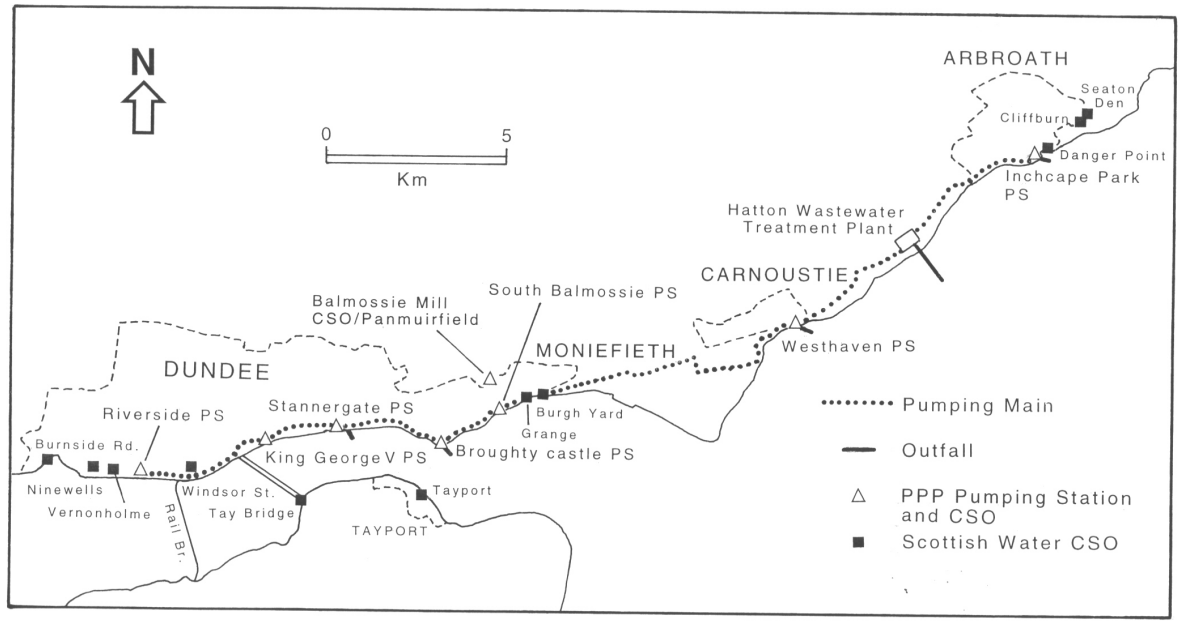

TAY WASTEWATER PROJECT : PFI \& SW NETWORK DETAILS

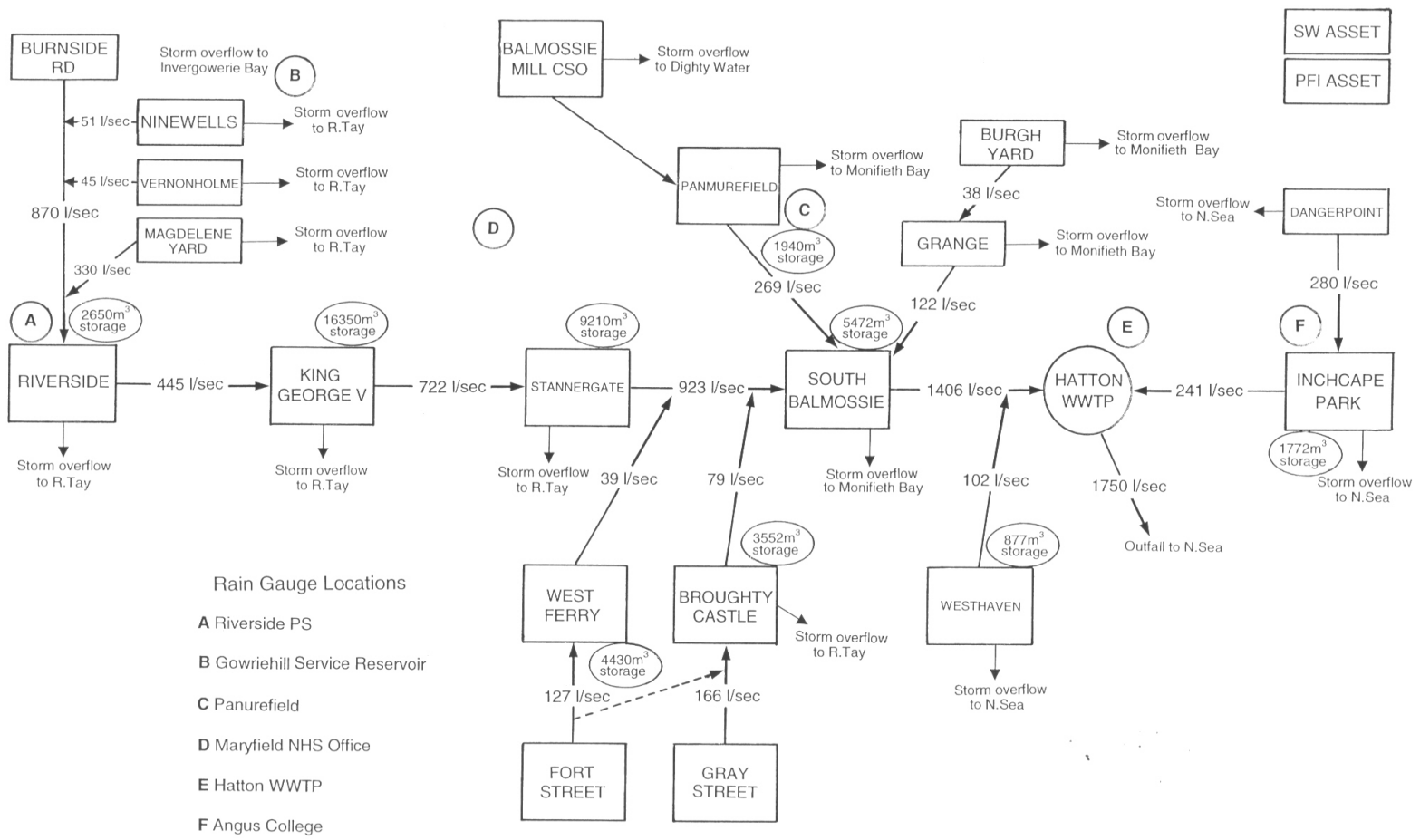

Fig. 2. The Tay Estuary Wastewater scheme courtesy of Scottish Water.

Carnoustie and Arbroath should meet the tighter guideline standards."

Colin Anderson, SEPA Dundee Area Team Leader (pers. comm.)

\section{Sample collection and storage}

At each site, temperature and salinity were measured using a Partech TCS/81 probe. Bed surface sediment samples (top
$10 \mathrm{~cm}$ ) were collected using a modified van Veen grab (with added teeth) from aboard the University of Dundee's R.V. Mya at high slack water. Samples were transferred onto nonwaxed aluminium foil for transportation. In the lab they were stored, in darkness, in solvent washed glass containers. Samples were frozen as soon as possible after collection.

Sediments were sampled in a grid pattern (Fig. 1; one sample at each location). The total water depth above the sediment was c. 2-3 $\mathrm{m}$ at high water. Control samples from the outer estuary were collected by the Marine Research 
Table 2. Optimal operating conditions.

\begin{tabular}{lll}
\hline & GC-FID & GC-MS \\
\hline Column & $\mathrm{HT}-5(25 \mathrm{~m} \times 0.22 \mathrm{~mm} \times 0.1 \mu \mathrm{m})$ & $\mathrm{HT}-5(25 \mathrm{~m} \times 0.22 \mathrm{~mm} \times 0.1 \mu \mathrm{m})$ \\
Helium & $0.6 \mathrm{kPa}$ & $0.6 \mathrm{kPa}$ \\
Injection & $2 \mu \mathrm{l}$ & $2 \mu \mathrm{l}$ \\
Injector & $50^{\circ} \mathrm{C}$ to $300^{\circ} \mathrm{C} @ 12^{\circ} \mathrm{C} / \mathrm{sec}$ & \\
Injection system & & $50^{\circ} \mathrm{C}$ to $3295^{\circ} \mathrm{C} @ 12^{\circ} \mathrm{C} / \mathrm{sec}$ \\
Oven & $50^{\circ} \mathrm{C}$ for $1 \mathrm{~min}$, & $50^{\circ} \mathrm{C}$ for $1 \mathrm{~min}$, \\
& $45^{\circ} \mathrm{C} / \mathrm{min}$ to $230^{\circ} \mathrm{C}$, & $30^{\circ} \mathrm{C} / \mathrm{min}$ to $250^{\circ} \mathrm{C}$, \\
& $230^{\circ} \mathrm{C}$ for $1 \mathrm{~min}$, & $250^{\circ} \mathrm{C}$ for $1 \mathrm{~min}$, \\
& $3{ }^{\circ} \mathrm{C} / \mathrm{min}$ to $300^{\circ} \mathrm{C}$, & $2.5^{\circ} \mathrm{C} / \mathrm{min}$ to $292^{\circ} \mathrm{C}$, \\
& $300^{\circ} \mathrm{C}$ for $5 \mathrm{mins}$ & $292^{\circ} \mathrm{C}$ for $5 \mathrm{mins}$ \\
FID & $320^{\circ} \mathrm{C}$ & \\
Transfer line to $\mathrm{MSD}$ & & $295^{\circ} \mathrm{C}$ \\
\hline
\end{tabular}

Laboratory (MRL) Aberdeen, using the same procedure. Further control samples were also collected from the Middle Bank (J to N; Fig. 1) and upstream mudflats to the west of Invergowrie Bay (E to I; Fig. 1).

\section{Analytical procedures}

Twenty gram sub-samples of sediment were refluxed in $6 \%$ $\mathrm{w} / \mathrm{v} \mathrm{KOH}$ in methanol for $4 \mathrm{~h}$. The cooled supernatant was decanted and centrifuged to remove remaining solids ( $5 \mathrm{~min}$ at $500 \mathrm{rpm})$. Non-polar sterols were partitioned into hexane after the addition of pure water (after Mudge and Norris, 1997). All appropriate measures were taken to minimise potential contamination. An attempt was made to establish the use of a novel internal standard, 1-docosanol. However, it was found that docosanol also occurred in the sediments and therefore was unsuitable for the purpose. It was not possible to distinguish between 1-docosanol and an epimer in the sediments and so absolute identification was not possible. It is suggested that the soft fruit industry on the Carse of Gowrie (north shore of Tay Estuary) may be the source of the alcohol. Docosanol has been isolated from raspberry strains grown there (Scottish Crop Research Institute, pers. comm.) An external standard (4 $\mu \mathrm{g} 5 \alpha$-cholestane in $100 \mu \mathrm{l}$ heptane) was therefore added. Based on preliminary experimentation, extraction efficiency (reported to be essentially $100 \%$ by Mudge and Norris, 1997) was found to average $>90 \%$; a result which compares favourably with reported extraction efficiencies using this protocol (62\%-96\%: LeBlanc et al., 1992). Sterols were derivatised using $100 \mathrm{ml}$ of $1: 10$ TMCS/BSFTA at $60^{\circ} \mathrm{C}$ for $1 \mathrm{~h}$.

Identification of unknowns was achieved by comparison of relative retention times with authentic standards on GC-MS (GC as GC-FID; transfer $295^{\circ} \mathrm{C}$; Hewlett-Packard 5790B MSD; control/data handling by Hewlett-Packard ChemSta- tion; SIM scanning through 50-520 atomic mass units (amu), 1 scan per second).

Quantification was achieved by use of calibration curves (average error $6.21 \%$ ) based on the repeated injections of eight standards (Aldrich) onto GC-FID (Phillips PU4400 GC, with cool on-column injection by Phillips PU4400/23; operating conditions are stated in Table 2). Least squares regression analysis was used to give a best estimate of the amount of sterol on-column in micrograms within $+/-1$ confidence interval. Within these working conditions, over 20 injections, retention time variation was $<1 \%$ and detector response showed a c. $2.5 \%$ variation. Testing the limit of detection of the GC-FID showed that $10 \mathrm{ng}$ of sterol on-column could be reliably resolved.

\section{Results and discussion}

Results presented in this paper represent data initially collected during the spring and summer months of 1997. The introduction of Hatton Sewage Treatment Works means that the historical significance of these data has greatly increased. They have come to represent baseline concentrations of biomarkers measurable in contaminated sediments. As the Hatton PFI scheme is now fully operational, a substantial reduction in the degree of anoxicity of the sediment plus associated sterol reduction should have ensued.

The composition of the effluent discharged into the estuary was likely to have remained relatively consistent over the study period, as the population of Dundee does not fluctuate greatly on a seasonal basis. Given that conditions in the catchment were substantially unchanged, Kelly's (1995) assumption (that the gross composition of sewage does not change significantly over time) is upheld.

Jeng et al. (1996) reported difficulties in separating coprostanol and epicoprostanol on-column. The chromatographic techniques used here clearly resolved coprostanol 
and epicoprostanol based upon their different cis- and transstructures by lengthening the retention time. Once it had been established that there was not a significant amount of epicoprostanol in the sediments, coprostanol and epicoprostanol were considered together in ratios, following the precedent set by Venkatesan and Kaplan (1990), Sherwin et al. (1993), Jeng et al. (1996), Sherblom et al. (1997), Chan et al. (1998) and Marvin et al. (2001). In particular, the authors showed that in ratios such as $5 \beta /(5 \alpha+5 \beta)$, the combination of coprostanol and epicoprostanol can elucidate the presence or absence of faecal material more clearly than on the basis of coprostanol alone.

Particle size analysis was performed using a Coulter LS 230 laser diffraction particle size analyser, which can measure over a size range of 0.4 to $2000 \mu \mathrm{m}$.

Sediments were sand dominated with small variable amounts of clay and silt particles. Sand accounted for 65$98 \%$, silt for $1.5-30 \%$ and clay for $1-4 \%$ of the size distribution in Invergowrie Bay.

Sterols were most strongly related to the silt fraction of the sediments. For example, the relationship between coprostanol and silt was $\mathrm{R}^{2}=0.56$, whereas with clay, $\mathrm{R}^{2}=0.4$. Cholesterol, on the other hand, was most strongly associated with clay $\left(R^{2}=0.5\right)$. Statistical relationships between grain size and sterol content demonstrated declining sterol concentrations with increasing sand content. These results concur with those of other authors (e.g. Hatcher and McGillivary, 1979; Bachtiar et al., 1996). These authors highlight the significance of the association between Total Organic Matter (TOM) content and sediment particle size. The implication of the work is that the primary source of silt and clay sized sediments was also the primary source of the organic fraction. TOM was established for all samples (ashing for $3 \mathrm{~h}$ at $1000^{\circ} \mathrm{C} ; 10 \mathrm{~g}$ dry sediment) and accounted for $1.25-5.00 \%$ of the total sediment (Table 3 ).

It can be seen from Table 4 that there was a substantial overall reduction in recorded sterol concentrations over the spring and summer months. This month-on-month loss (April-August) was as high as 60\% for coprostanol, 53\% for epicoprostanol, $41 \%$ for cholesterol and $24 \%$ for cholestanol. The differences in sterol reductions reflect differences in degradation behaviour in aerobic surface sediments and inputs from sources other than the outfall. The decline in coprostanol reflects the maximum amount of sterol degradation. Due to its absolute source specificity, there was no interference from other (i.e. non-faecal) sterol sources.

When compared with temperature and salinity variations (Table 5), sterol reductions corresponded to an increase in ambient water temperature and salinity. The temperature changes, in particular, reflected improving conditions for microbial growth. It is suggested that the primary mechanism of sterol decline was due to microbial degradation, in agreement with the previous work of Huang and Meinschein (1979).

Microbes are a primary constituent of sewage (Ashley and Dabrowski, 1995) and an increased temperature will encour-
Table 3. Percentage TOM concentrations, Invergowrie Bay, AprilAugust.

\begin{tabular}{cccc}
\hline Month & Range $(\%)$ & Mean & Standard Deviation \\
\hline April & $1.50-4.70$ & 2.74 & 1.08 \\
June & $1.25-3.85$ & 2.09 & 0.67 \\
July & $1.35-5.00$ & 2.19 & 1.01 \\
August & $1.30-4.55$ & 2.22 & 0.85 \\
\hline
\end{tabular}

age mesophyllic bacterial groups common in sewage to become more active (Hammer, 1986). As a general rule, the activity of mesophyllic bacteria approximately doubles for every $10-15^{\circ} \mathrm{C}$ rise in temperature between $5-35^{\circ} \mathrm{C}$. The ambient sewage temperature in Dundee sewers increases from $7-9^{\circ} \mathrm{C}$ in winter to c. $16^{\circ} \mathrm{C}$ in summer and the number of faecal bacteria are higher in summer storms than winter periods (Ashley and Dabrowski, 1995). Based on the effluent temperature rise and general principles of mesophyllic bacterial growth, it is logical to assume that there was up to a doubling of mesophyllic bacterial activity in the sewage effluent over the study period.

Sewage provides a rich nutrient source for metabolism by these bacterial groups. It was supposed that in the sewer, aerobic sterol degradation by micro-organisms occurred where aerobic conditions were possible (the surface) and anaerobic degradation occurred elsewhere in the sewage stream where mixing with air to provide oxygen was negligible or nil (Hammer, 1986). Alongside the increased microbial activity was a longer summer residence time for sewage in the sewer prior to discharge. Decreased rainfall over the study period reduced the amount of storm water flow to the sewers. This increased the foul load of the sewage relative to the reduced total volume of effluent as domestic wastewater inputs remained constant (see Ferrier and Anderson, 1996).

Once sterol-bearing loads have been discharged via an outfall, their degradation in aerobic surface sediments is well recorded (Quemeneur and Marty, 1994; Marty et al., 1996; Leeming et al., 1998; O'Leary et al., 1999). Increasing ambient water temperatures and an abundant nutrient source would have encouraged increasing microbial activity in the sediments and water column. Maximum sedimentary microbial activity has been recorded on the Tay intertidal flats during summer months when surface sediment temperatures are greatest (Keith et al., 1987). Continued degradation of depleted sterol concentrations thus would be expected to occur in the sediments and water column.

After an effluent has been discharged via an outfall, the subsequent dilution is dependent upon the method of introduction, the vertical density gradient of the receiving water and the characteristics of estuarine flow. The mixing of effluent with the receiving water is due to molecular diffusion and the action of eddies generated by the main flow (Ferrier 
Table 4a. Mean monthly concentrations of sterols $\left(\mu \mathrm{gg}^{-1}\right)$ and reduction in concentration (\%).

\begin{tabular}{ccccc}
\hline Month & Coprostanol & Epicoprostanol & Cholesterol & Cholestanol \\
\hline April & 1.53 & 0.35 & 0.70 & 0.41 \\
June & 0.96 & 0.27 & 0.51 & 0.33 \\
July & 0.74 & 0.18 & 0.41 & 0.24 \\
August & 0.75 & 0.15 & 0.40 & 0.26 \\
Reduction $(\%)$ & 51 & 56 & 43 & 37 \\
\hline
\end{tabular}

Table 4b. Continued.

\begin{tabular}{ccccc}
\hline Month & Campesterol & Stigmasterol & $\beta$-sitosterol & Stigmastanol \\
\hline April & 0.35 & 0.41 & 1.70 & 0.41 \\
June & 0.28 & 0.35 & 1.18 & 0.33 \\
July & 0.19 & 0.24 & 0.73 & 0.24 \\
August & 0.16 & 0.18 & 0.78 & 0.24 \\
Reduction $(\%)$ & 55 & 56 & 56 & 41 \\
\hline
\end{tabular}

Table 5. Mean temperature $\left({ }^{\circ} \mathrm{C}\right)$ and salinity in Invergowrie Bay.

\begin{tabular}{ccc}
\hline Month & Temperature & Salinity \\
\hline April & 5 & 16 \\
June & 14 & 16 \\
July & 18 & 22 \\
August & 17 & 24 \\
\hline
\end{tabular}

and Anderson, 1996). Transportation is also partially dependent on currents in the receiving water and the velocity of the buoyant plume (Baker et al., 1995). In Invergowrie Bay, the necessary reduction in velocity required for deposition of particles did not occur immediately at the end of the outfall and so maximum deposition was at a distance from the outfall terminus. It is likely that this depositional pattern is a combination of the sewage stream velocity and the receiving water velocity, although the latter is expected to be more important in carrying the effluent away from the outfall.

The spatial distribution of total sterol concentrations in April clearly defined a plume (Fig. 3). Maximum deposition was at c. 150-200 m south east of the outfall and the plume appeared to be confined to the north shore. Areas of high concentration were associated with sediments with a high silt/clay and TOM content.

A different situation was observed over the summer months. Deposition at this time was immediately adjacent to the outfall in a typical semi-circular pattern that covered a small area (c. 50-100 $\mathrm{m}$ diameter), originally described by Alve (1995). The dispersion pattern represents a creation of a radial gradient in the sterol loading of the sediments and a local distance decay effect.

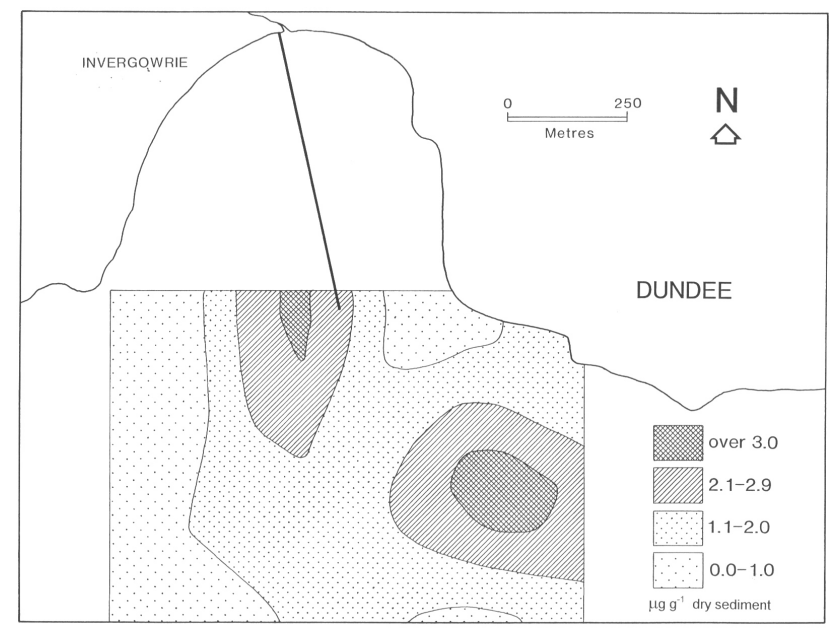

Fig. 3. Mapped total sterol distribution.

It is suggested that the changing condition of the sewage effluent was one of the major factors influencing the pattern of distribution at the outfall terminus. The rainfall conditions would have caused decreased effluent volume and the more viscous effluent would move more slowly. This would reduce the velocity at the point of discharge to the estuary. The increased viscosity would have resulted in a load that was less easily dispersed.

In conjunction with this, increased salinity was measured in the summer months. Salinity can encourage flocculation of solids discharged on contact with the receiving water (Burton and Liss, 1976). It is therefore likely that there was also increased flocculation as a consequence of the increased salinity and so organic particles (and thus sterols) were more 
rapidly sedimented out of the water column. It is probable that there was also a reduction in the receiving water velocity in Invergowrie Bay as tidal currents would not have been as enhanced by freshwater flow as at times of peak discharge (late winter/spring).

Analysis of sterols from Middle Bank indicates a significant marine sedimentary source, in keeping with work by Thornton and McManus (1994) which detected marine influences using isotopic determinations. Upstream concentrations were lower than in Invergowrie Bay, suggesting diminished importance of organic inputs from sewage and implying a dominant easterly movement of the sterol-laden sediments (Table 6).

Predominant winds are from the south-west and west (Ferentinos and McManus, 1981; McManus, 1986). A steady wind on an open area of shallow water can have a significant effect on the dominant direction of plume movement (Wewetzer, 1998). The predominant wind directions would be towards the north-east and east and it is surmised that this would help drive the plume eastwards to some extent. Due to the plume's buoyant nature, it is normally at least partially a near-surface feature.

When effluent is released into an estuary, the mixing of the fresher water with the ambient seawater produces a buoyant plume (Baker et al., 1995). The movement of particles along this plume would be assisted by the upward velocity of the plume initially, followed by dispersal of the plume and finally deposition. McManus (1984) noted the occurrence of warmer local effluent discharge causing thermal plumes along the Dundee foreshore. Ferrier and Anderson (1996) tracked thermal effluent plumes from the Invergowrie Bay outfall using remotely sensed images throughout a tidal cycle.

The dominant plume movement suggested by sedimentary sterol concentration data in this study concur with the remotely sensed data for plume movement on the ebb tide, reported by Ferrier and Anderson (1996). Coprostanol concentrations denoted a maximum deposition track eastward of the outfall, defining a plume moving along the north shore. Anisotropic behaviour such as this indicated a distribution pattern consistent with dominant current direction (Chan et al., 1998). Wind resuspension is known to be significant in the Tay Estuary (Weir and McManus, 1987). Strong winds, characteristic of April weather, contribute to higher suspended load concentrations than in calmer summer conditions (see Owen and Balls, 1997). It is suggested, therefore, that the resuspension and deposition of contaminated sediments contributed to concentrations along the maximum depositional track.

Ferrier and Anderson (1996) also demonstrated the restriction of effluent flow to the north shore of the estuary with data from Eschericia coli combined with remote sensing studies. The E. coli data clearly showed a lack of southwards dispersion during the end of the flood and first half of the ebb tide. Numbers of $E$. coli bacteria increased from 1800 per $100 \mathrm{ml}$
Table 6. Total sterol concentrations $\left(\mu \mathrm{g} \mathrm{g}^{-1}\right)$.

\begin{tabular}{cc}
\hline Sample site & Concentration \\
\hline Middle Bank & \\
A & 8.45 \\
B & 5.84 \\
C & 0.34 \\
D & 0.24 \\
Upstream & \\
E & 0.27 \\
F & 0.12 \\
G & 0.00 \\
H & 0.27 \\
I & 0.12 \\
Downstream & \\
J & 5.56 \\
K & 4.05 \\
L & 1.21 \\
M & 5.26 \\
N & 3.55 \\
\hline
\end{tabular}

Values are averages of duplicates.

one hour before high water to 19600 per $100 \mathrm{ml}$ four hours after high water (Ferrier and Anderson, 1996 and 1997b).

Remote sensing studies have shown that the occurrence of an estuarine front was the main feature restricting effluent dispersal during the ebb tide (Ferrier and Anderson, 1996; Ferrier and Anderson, 1997a and b). The longitudinal advective front associated with channel topography displayed a strong colour and temperature contrast (Ferrier and Anderson, 1996, 1997a and b). Such fronts denote boundaries between water bodies defined by different density conditions on either side of the interface (Reeves and Duck, 2001). They have particular significance for organic inputs, like sewage, as they can concentrate buoyant organisms and contaminants (Simpson and Turrell, 1986; Brown et al., 1991). The complex pattern, relatively short formation and decay time of these fronts suggests they are the result of intratidal and lateral density dynamic balance (Ferrier and Anderson, 1997b).

As there was evidence to indicate the accumulation of sewage derived materials in the near vicinity of Dundee, it was considered that while there was limited upstream dispersal, the majority of sewage was deposited along a downstream track near to Dundee. Organic matter in the outer estuary, however, is characterised by tidally introduced signatures (Thornton and McManus, 1994), suggesting the decreased importance of sewage derived organics and possible containment of polluted sediments in the middle estuary. There is also evidence for poor dispersal of pollutants in the middle estuary, particularly at times of low flow when residence times increase (Hubbard and Hashim, 1987; Owen and Balls, 1997). This raises questions about the potential environmental impacts from sewage in such depositional hot spots. 
Individual sterol distributions for April showed a welldefined plume orientated west-east and originating in Invergowrie Bay. This was particularly visible for coprostanol. Maximum concentrations were noted at a distance from the outfall (c. 150-200 m south east). This suggested that coprostanol concentrations were affected by variables such as flocculation (which would alter particle size and therefore trajectory and fall velocity through the water), effluent stream velocity and local current conditions (Bachtiar et al., 1996).

Higher concentrations were also noted at the end of the outfall, declining with distance from the outfall. This trend is compatible with mixing/dilution patterns reported by Bachtiar et al. (1996). Initial deposition of larger particles would occur at the outfall terminus with flocculation on contact with the higher salinity estuarine water.

It is feasible that resuspension of sterol-bearing sediments occurs as the tide turns. These particles would then be carried along the plume track prior to redeposition. Based on the importance of wind-resuspension of sediments (Weir and McManus, 1987), the contribution may be significant under appropriate weather conditions (i.e. wind-driven waves and currents resuspending bottom sediments) in the shallow waters over the intertidal mudflats.

By June, sterol distributions were constrained along the north shore. The April and June coprostanol distributions suggested the plume was a dynamic and ephemeral feature, defined by shifting tidal currents and effluent characteristics. The same pattern of sterol distribution (i.e. decreasing concentrations with distance from the outfall) was carried through the sterol suite. In both the April and June sample sets, maximum deposition patterns suggest dominant plume movement was west to east. It is proposed that the dominant movement of sterols and thus sewage was towards the north sea, with little upstream transference (Patton, 1998; Patton and Reeves, 2001). Lower concentrations of coprostanol upstream as compared to Invergowrie Bay, and the occurrence of cholesterol instead of coprostanol as the primary sterol, suggest that sewage was not as important as other sources of sterols at this location. Downstream concentrations (Table 6) support this hypothesis as these were the highest recorded in this study. These downstream values indicated the accumulation of sterol-laden sediments with distance downstream from Invergowrie Bay. A phenomenon like this is significant; the combination of different sewage discharges and contaminant accumulation has implications for estuarine management.

Proposed recommendations for the management of the tidal mudflats concentrate on the obligations and options to monitor and encourage both ecological potential and geomorphological diversity (under the Water Framework Directive 2000/60/EC). Management solutions based on individual estuaries are uncommon. Ideally, the recommendation of this study would be that environmental regulators take into account both the precautionary principle (removal of sewage effluent inputs) and the environmental capacity (level of as- similation prior to damage occurring in the system). The Tay is capable of assimilating the bulk of organic contaminants by flushing, burial, microbial degradation and sediment transport. Intertidal flats are inherently dynamic and reliant upon local sediment supply and prevailing currents.

The study demonstrated that sterol distributions exhibited a clearer distance decay effect as the summer progressed. This was particularly apparent in distributions of coprostanol and cholesterol. The changes in distance decay of the sterol concentrations were possibly linked to the declining amounts of sterols measured and change in deposition.

The $\beta$-sitosterol concentrations in the August distributions showed the clearest evidence in support of an incursion of sterols from outwith the study area. Comparison of this anomaly with sediment data, however, showed that sediments at this site (D3; see Fig. 1) have a high silt content. The elevated sterol concentration observed in the majority of samples taken in August at this site was therefore more likely to be a consequence of the local preferential deposition of sterol-laden silt-sized sediments rather than the influence of a separate sterol source external to the study area (e.g. Coprostanol $1.06 \mu \mathrm{gg}^{-1} ; \beta$-sitosterol $1.81 \mu \mathrm{gg}^{-1}$ ).

Suspended sediment in the middle estuary is subject to strong circulation patterns caused by the interaction of tidal and riverine flows. These combine with an observed figureof-eight circulation pattern to create a middle estuary sediment sink (Hashim, 1985; Hubbard and Hashim, 1987). Movement of sediments seawards is also offset by landwards migration in this area (Al-Dabbas, 1980; Al-Dabbas and McManus, 1987). The difference in tidal input (spring/neap) makes no significant difference to the pattern of circulation (Hashim, 1985). The existence of a sediment sink near Dundee, stated in the work cited above, indicates that sewage-contaminated sediments can be deposited and resuspended several times in the upper-middle estuary prior to permanent burial or loss to the sea. Hubbard and Hashim (1987) showed much of this activity took place on the north shore mudflats. The apparent accumulation of sterols, in particular coprostanol, in the downstream sediments backs up this theory.

Given the aforementioned grain size effect and the importance of measuring a sterol suite, as well as other impacting physicochemical and degradation parameters (Jeng and Han, 1994), the level of coprostanol alone is insufficient to describe the sewage related sterols in a given sediment. A significant number of authors (Hatcher and McGillivary, 1979; Saliot and Tusseau, 1984; Venkatesan and Kaplan, 1990; Grimault et al., 1990; Tian et al., 1992; Jeng and Han, 1994; Quemeneur and Marty, 1994; Takada et al., 1994; Chalaux et al., 1995; Li et al., 1995; Fattore et al., 1996; Nichols et al., 1996; Chan et al., 1998) have therefore suggested that appropriate independent ratios are a better instrument for comparison and trend identification purposes (i.e. a normaliser for grain surface area effects). These indices are based primarily on the use of coprostanol, cholesterol and cholestanol. 
The sterols listed are the best qualified to act as indicators of sewage inputs (Writer et al., 1995) due to similarities between their solubility, binding characteristics and decay rates (Hatcher and McGillivary, 1979).

Ratios of sterols were calculated in order to elucidate sources and examine the possibility of degradation, principally by microbial organisms. The use of ratios involves assumptions as to the behaviour of sterols in the natural environment. The most significant of these is that all sterols have the same stability in surface sediments and that sterol distribution is constant, with the exception of the anthropological input of coprostanol.

Three ratios $(5 \beta /(5 \alpha+5 \beta)$ stanol index, coprostanol/epicoprostanol (c/e) index, coprostanol/cholesterol (c/ch) index) were applied in order to prove primary source. Due to the location of the sample sites, the most likely source of sterols was the sewage outfall and the indices were expected to confirm this. The $5 \beta /(5 \alpha+5 \beta)$ ratio was the principal ratio and the coprostanol/epicoprostanol and coprostanol/cholesterol ratios allowed cross-validation of results.

The $5 \beta /(5 \alpha+5 \beta)$ ratio aids discrimination of sewage and biogenic sources (Grimault et al., 1990). Both the concentrations of coprostanol and the $5 \beta /(5 \alpha+5 \beta)$ ratio were needed to elucidate the relative contribution of sewage sources and natural reduction sources of sterols to the sedimentary sterol budget (Grimault et al., 1990; Fattore et al., 1996). The application of the index produces a value of 1 or less which indicates the relative degree of pollution (Table 7). Studies by Jeng and Han (1994) and Fattore et al. (1996) confirmed values of $>0.7$ as indicative of urban sewage pollution and concluded that this ratio is a very useful tool for the elucidation of sources of sterol input to recent sediments. The equation for deriving the index is stated as:

$\frac{(\text { coprostanol }+ \text { epicoprostanol })}{((\text { coprostanol }+ \text { epicoprostanol })+\text { cholestanol })}$

Values of 0.76 to 0.90 (standard deviation $=0.04$ ) for April data demonstrated unambiguous sewage pollution in the samples. As would be expected, ratios indicated urban sewage pollution during the entire study period (June range $0.65-0.90$, standard deviation $=0.05$; July range $0.66-0.88$, standard deviation $=0.65$; August range $=0.63-1.00$, standard deviation=0.10). The application of the Kruskall-Wallis statistic to the ratios showed significant differences in the month to month values $(\mathrm{p}=0.005)$. Mean values are shown in Table 7.

The coprostanol/epicoprostanol (c/e) index differentiated human waste from other faecal sources of coprostanol (Fattore et al., 1996). Reported values of this ratio typically representative of a human source were 1.55 to 6.00 (Fattore et al., 1996; Venkatesan and Kaplan, 1990; Jeng and Han, 1994), although values as high as 13.24 (inside Venice city boundary) have been reported (Fattore et al., 1996).
Table 7. Mean values for $5 \beta /(5 \beta+5 \alpha)$, c/e and c/ch indices, Invergowrie Bay, April-August.

\begin{tabular}{cccc}
\hline Month & $5 \beta /(5 \beta+5 \alpha)$ & $\mathrm{c} / \mathrm{e}$ & $\mathrm{c} / \mathrm{ch}$ \\
\hline April & 0.81 & 4.82 & 2.08 \\
June & 0.77 & 3.25 & 1.79 \\
July & 0.74 & 2.87 & 1.65 \\
August & 0.77 & 3.38 & 1.67 \\
\hline
\end{tabular}

Values obtained for the c/e ratio in Invergowrie Bay (Table 7) fell within reported ranges confirming a human source of faecal sterols (April range $=2.22-15.60$, standard deviation $=3.05$; June range $=1.63-6.46$, standard deviation $=1.40$; July range $=1.00-12.89$, standard deviation $=2.87$; August range $=1.12-9.81$, standard deviation $=2.40$ ). Sewage, therefore, was the primary faecal sterol source. The KruskallWallis statistic again showed these differences to be very significant $(\mathrm{p}=0.008)$. The coprostanol/epicoprostanol ratio appeared to be excessively high at sites A4 (April) at 15.60 and site $\mathrm{A} 3$ (July) at 12.89. Values along the sites to the east (sites $\mathrm{J}-\mathrm{N}$, range 2.93-6.73) and west (sites $\mathrm{A}$ and $\mathrm{B}$, range 1.81-2.63) of Invergowrie Bay also demonstrated a human source of sterol input.

The coprostanol/cholesterol (c/ch) ratio elucidated the contribution of different biogenic sources. Ratios of $<1$ are reported to indicate a biogenic source and $>1$ to indicate a sewage source (Fattore et al., 1996; Nichols et al., 1996). A biogenic input would have indicated a secondary source of organic matter, e.g. macrophytes.

The Invergowrie Bay samples (Table 7) across the whole study period displayed no secondary source of organic matter (April range 1.20-3.11, standard deviation $=0.44$; June range $=1.39-3.02$, standard deviation $=0.35$; July range $=0.80-2.70$, standard deviation $=0.42$; August range $=0.81-2.43$, standard deviation $=0.40$ ). Most values fall within or close to reported ranges for raw sewage ( $>1$ to $<4$; Quemeneur and Marty, 1994; Takada et al., 1994). It was expected that some values should fall outwith this range as dilution of raw sewage occurred with distance from the outfall. As with the previous two indices, the Kruskall-Wallis statistic revealed significant differences in the index values over the study period $(\mathrm{p}=0.008)$.

The sites west of Invergowrie Bay, however, displayed values $<1$ (with one exception, site $\mathrm{L}=1.41$ ) and an average of 0.75 . This implied a biogenic source of cholesterol was contributing to the sterol loading upstream of the majority of sewage loadings. The non-sewage source has not been identified, but it was likely to be from a combination of sedimentary, aquatic and terrestrial sources (in particular, marginal macrophytes).

Urban sewage pollution was definitely identified by the $5 \beta /(5 \alpha+5 \beta)$ stanol index along the estuary. The dominance 
Table 8. Means of $\mathrm{C}_{27}$ and $\mathrm{C}_{29}$ stanol/sterol ratios and Chalaux ratio.

\begin{tabular}{cccc}
\hline & $\mathrm{C}_{27}$ & $\mathrm{C}_{29}$ & Chalaux \\
\hline April & 0.64 & 0.31 & 0.63 \\
June & 0.68 & 0.30 & 0.61 \\
July & 0.63 & 0.39 & 0.65 \\
August & 0.72 & 0.30 & 0.61 \\
\hline
\end{tabular}

of sewage as a sterol source was also confirmed by the c/e and $\mathrm{c} / \mathrm{ch}$ indices. Later in the season, inconclusive sterol sources (ratio values $>0.6$ and $<0.7$ ) were noted at the southern limit of the Invergowrie Bay sample area and corresponded to low coprostanol concentrations. The frequency of their occurrence increased across the study period (min. April=0; max. August $=6)$ in response to the falling sterol concentrations. The $5 \beta /(5 \alpha+5 \beta)$ stanol index suggested a distance decay effect consistent with concentration data. This was verified by the c/e index. The distance decay feature was expected, as there is much evidence in the literature to show significant distance decay effects in concentrations within a few hundred metres of outfall termini (e.g. Alve, 1995; Leeming and Nichols, 1998).

The $5 \beta /(5 \alpha+5 \beta)$ stanol index values suggested some spread of the sewage plume upstream on the flood tide. As mentioned previously, the movement of the plume upstream has been defined by remote sensing studies (Ferrier and Anderson, 1996) and the data suggested there was limited deposition upstream. It was impossible, however, to distinguish effluent from the Invergowrie Bay outfall from the small sewage inputs upstream (serving individual houses or small communities) without tracer studies. The lower values of the c/e ratio to the west of Invergowrie Bay reflect the downward trend in coprostanol concentrations, as there was no major outfall upstream of Dundee. The small outfalls upstream of Dundee were expected to contribute significantly to the urban sewage 'fingerprint' noted at the upstream sites.

The decline in the $5 \beta /(5 \alpha+5 \beta)$, c/e and c/ch average values from April to August (Table 7) is congruent with the falling coprostanol concentrations. The c/ch index indicates the increasing spatial importance of non-sewage derived cholesterol with distance from the outfall. The increasing temporal importance of non-sewage cholesterol was indicated by the decreasing values (suggested by the decreasing means).

The reduction of sterols by microbial action can have a significant effect upon the sterol "fingerprint" (Tian et al., 1992). In order to examine the possibility of sterol degradation, two means of assessing the data were used for cross validation purposes. These were the cholesterol/(cholesterol + cholestanol) index and $\mathrm{C}_{27}$ and $\mathrm{C}_{29}$ stanol/sterol pairs. The indication of reduction lies in the relationship between stanol and sterol, where sterols are reduced to their stanol form by microbial action. The higher relative concentration of the stanol form, the higher the potential level of reduction (Tian et al., 1992).

Chalaux et al. (1995) explored the use of a version of $5 \beta /(5 \alpha+5 \beta)$ ratio to examine the occurrence of reduction of sterols in the following form:

cholesterol/(cholestanol + cholesterol)

Chalaux et al. (1995) reported index values of $<0.5$ in inner Tokyo Bay, which suggested that there was reduction of cholesterol at this location. The authors also report ratios of $0.88-0.4$ in the water particulate phase and 0.4 in sediments. This indicats the reduction of sterols in anoxic sediments leading to the formation of the $5 \alpha$ - and $5 \beta$-stanol isomers. The smaller the index value, the more reduction has occurred.

Changes in the Chalaux index (Table 8) were seen locally and a general decrease in the ratio from the north to south of the Invergowrie Bay sample site implied increased reduction in samples from April (range 0.52-0.85; mean 0.64; s.d.=0.90), June (range $0.17-0.77$; mean 0.61 ; s.d. $=0.05$ ) and July (range $=0.53-0.84$; mean $=0.65$; s.d. $=0.09$ ) with distance from the outfall. The exception to this was August (range 0.51-1.00; mean=0.65; s.d.=0.09). The strongest evidence for sterol alteration in August was seen at sites C1 (0.51), B4 (0.52) and B3 (0.54).

Used with caution (Gaskell and Eglinton, 1975), stanol/sterol ratios have the potential to estimate the degree of biohydrogenation efficiency, leading to the transformation of sterols into stanols (Saliot and Tusseau, 1984; Tian et al., 1992; Li et al., 1995). The indices required the assumptions that there was a higher stability of stanols versus sterols, with direct reduction of sterols under anoxic conditions and that biohydrogenation of sterols by microorganisms occurred in the water column and surface sediments (Lajat et al., 1990).

Li et al. (1995) reported on the simultaneous measurement of a $\mathrm{C}_{27}$ pair (cholestanol/cholesterol) and a $\mathrm{C}_{29}$ pair (stigmastanol/sitosterol) in the Serayu River system in Indonesia. They suggested that the low values (mean 0.3 ) for the 27 pair and less again for the 29 pair indicated that allochthonous organic matter was more resistant than autochthonous to degradation by microorganisms. Saliot and Tusseau (1984) have applied these ratios to the marine environment and Tian et al. (1992) have applied the same sterol/stanol ratios to sewage polluted estuarine sediment, thus establishing a precedent for its use in this study.

Table 8 presents mean values for a $\mathrm{C}_{27}$ stanol/sterol ratio (cholestanol/cholesterol) and $\mathrm{C}_{29}$ stanol/sterol ratio (stigmastanol $/ \beta$-sitosterol). The former is related to the reduction of autochthonous material (i.e., originating in situ) and the latter to the reduction of allochthonous material (i.e., originating ex situ; Li et al., 1995).

In general, in keeping with the work described in the literature (e.g., Li et al., 1995), the $\mathrm{C}_{27}$ ratios are higher than 
the $\mathrm{C}_{29}$ ratios. This finding indicates that degradation of allochthonous sterols was occurring. Despite the lack of spatial pattern in the index values, it can be seen that there is considerable variation in the amount of reduction occurring on a site to site basis. This suggests that there were very localised differences in the water column and sedimentary processes across the study area. It is also likely that changes in redox conditions occurred in the effluent prior to discharge.

The increasing activity of the microbial communities over the period April - August 1997 was indicated by the rise in the $\mathrm{C}_{27}$ ratio values (Tian et al., 1992). The change was minimal and not statistically significant. The increased values simply show increased microbial degradation of the sterols. This was congruent with the fall in measured sterol concentrations.

The Chalaux ratio did not show evidence for reduction to the extent reported by Chalaux et al. (1995). Values determined in the current work did not fall below the reported value of 0.5 , but did suggest that reduction was occurring. The overall picture was one of very similar sediment conditions during the entire study period as there was no great difference amongst the mean of the ratios $(0.63,0.61,0.65$, and 0.61). This was a consequence of the input of sterols and sewage particulate matter blanketing the surface sediments over the relatively small sample area.

Changes in the Chalaux ratio were interpreted with caution. Without additional evidence, it was difficult to say categorically that the measured effect was a direct consequence of reduction reactions in sediments. Variability in the amount of the sterols was dependent upon factors such as the diversity of inputs from the biomass and the intensity of degradation processes occurring prior to sedimentation (for example see Saliot and Tusseau, 1984). The evidence suggests that there is reason to infer limited reduction of sterols to stanols and that this degradation increased over the study period. The ratio, however, was not sufficiently sensitive to define changes very clearly.

The stanol/sterol ratio results give a better impression of the hydrogenation occurrence than the Chalaux ratio. The examination of sterol degradation using these ratios is generally more sensitive than the Chalaux ratio. The latter was, however, useful in suggesting that changes were occurring and in cross-validating the results from the stanol/sterol pairs.

\section{Conclusions}

Substantial overall reductions in sterol concentrations were recorded during the study. Average reductions in concentation were $60 \%$ for coprostanol, 53\% for epicoprostanol, $41 \%$ for cholesterol and $24 \%$ for cholestanol. Decreases in concentration were primarily a consequence of a doubling of mesophyllic bacterial activity. Spatial distributions of total sterol concentrations defined a plume at the start of the ebb tide, with a maximum deposition at a distance from the long outfall terminus. The plume was confined to the north shore. Deposition at high slack water was in a semi-circular pattern. Local currents were considered more important in plume formation than velocity of sewage flow. A distance decay effect was observed eastwards along the estuary. Individual sterols showed a plume present in April. Maximum coprostanol concentrations were observed $150-200 \mathrm{~m}$ from the outfall, suggesting dependence on variables such as flocculation and falling effluent stream velocity. The plume was a dynamic and ephemeral feature defined by shifting tidal currents. Plume movement was constrained to the north shore of the estuary on the ebb tide. High sterol concentrations identified at the end of the outfall were consistent with reported mixing and diution pattern.

The $5 \beta(5 \alpha+5 \beta)$ ratio indicated upstream movement of sewage. Results show a decline in the importance of sewagederived sterols the further west the samples were taken from Invergowrie. The coprostanol/epicoprostanol index was used to differentiate between human and non-human faecal inputs to the estuary. The index confirmed a human source for the faecal inputs. Domestic sewage was the primary source. The coprostanol/cholesterol ratio was used to calculate the contribution of different biogenic sources to the sedimentary sterol budget. Invergowrie Bay displayed no sterol source other than the sewage outfall. A biogenic source of cholesterol was influencing sterol concntrations upstream of Dundee (confirmed by the $\mathrm{C}_{27}$ ratio), where sewage inputs were lower. The source was likely to be a combination of natural sedimentary, terrestrial and aquatic sources.

$\mathrm{C}_{27}$ and $\mathrm{C}_{29}$ ratios were used to calculate the degree of transformation (sterol degradation). Higher values were obtained for $\mathrm{C}_{27}$ ratios, indicating a greater resistance to degradation of the autochthonous material. Increases in the $\mathrm{C}_{27}$ ratio suggest increases in microbial degradation of organic matter. This is in keeping with theories concerning the increase in sterol degradation over the summer period.

The Chalaux ratio indicated local variation in rates of sterol reduction. The strongest evidence of reduction was noted in samples taken in August.

Edited by: H. H. Savenije

\section{References}

Al-Dabbas, M. A. M.: An examination of shell fragment distribution and geochemical features of Mytilus edulis in the Tay estuary, $\mathrm{PhD}$ thesis, University of Dundee, 1980.

Al-Dabbas, M. A. M. and McManus, J.: Shell fragments as indicators of bed shell transport in the Tay estuary, Proceedings of the Royal Society of Edinburgh, 92B, 335-344, 1987.

Alve, E.: Benthic foraminiferal responses to estuarine pollution: a review, Journal of Foraminiferal Research, 25(3), 190-203, 1995. 
Ashley, R. M. and Dabrowski, W.: Dry and storm weather transport of coliforms and faecal streptococci in combined sewage, Water Science and Technology, 31(7), 311-320, 1995.

Bachtiar, T., Coakly, J. P., and Risk, M. J.: Tracing sewage contaminated sediments in Hamilton Harbour using selected geochemical indicators, Science of the Total Environment, 179, 316, 1996.

Baker, E. K., Harris, P. T., Kensett-Smith, B., Bagster, D. F., and Nobbs, D. M.: Physical properties of sewage particles in seawater, Marine Pollution Bulletin, 30(4), 247-252, 1995.

Benfenati, E., Cools, E., and Fattore, E.: A GC-MS method for analysis of faecal and plant sterols in sediment samples, Chemosphere, 29(7), 1393-1405, 1994.

Brown, R. C. and Wade, T. L.: Sedimentary coprostanol and hydrocarbon distribution adjacent to a sewage outfall, Water Research, 18(5), 621-632, 1984.

Brown, J., Turrell, W. R., and Simpson, J. H.: Aerial survey of axial convergent fronts in U.K. estuaries and the implications for pollution, Marine Pollution Bulletin, 22(8), 397-400, 1991.

Buller, A. D., Green, C. D., and McManus, J.: Dynamics and sedimentation: the Tay in comparison with other estuaries, in: Near shore sediment dynamics, edited by: Hails, J. and Carr, A. S., Wiley, London, pp. 201-249, 1975.

Burton, J. D. and Liss, P. S. (Eds.): Estuarine Chemistry, Academic Press, London, pp. 1-36, 1976.

Chalaux, N., Takada, H., and Bayona, J. M.: Molecular markers in Tokyo Bay sediments: sources and distribution, Marine Environmental Research, 40(1), 77-92, 1995.

Chan, K. H., Lam, M. H. W., Poon, K. F., Yeung, H. Y., and Chiu, T. K. T.: Application of sedimentary faecal stanols and sterols in tracing sewage pollution in coastal waters, Water Resources, 32(1), 225-235, 1998.

Cracknell, A. P., Hayes, L. W. B., and Keltie, G. F.: Remote sensing of the Tay estuary using visible and near infrared data: mapping of the intertidal zone, Proceedings of the Royal Society of Edinburgh, 92B, 223-236, 1987.

CSIRO: Commonwealth Scientific and Industrial Research Organisation, website: http://www.marine.csiro.au/ResProj/ CoasEnvMarPol/biomarkers.html, 2000.

Elhmalli, M. M., Roberts, D. J., and Evershed, P.: Bile acids as a new indicator class of sewage pollution indicator, Environmental Science and Technology, 31, 3663-3668, 1997.

Elhmmali, M. M., Roberts, D. J., and Evershed, R. P.: Combined analysis of bile acids and sterols/stanols from riverine particulates to assess sewage discharges and other feacal sources, Environmental Science and Technology, 34(1), 39-46, 2000.

Evershed, R. P. and Bethell, P. H.: Application of multimolecular biomarker techniques to the identification of faecal material in archaeological soils and sediments, A.C.S. Symposium Series, 625, 157-172, 1996.

Fattore, E., Benfenati, E., Marelli, R., Cools, E., and Fanelli, R.: Sterols in sediments from Venice lagoon, Italy, Chemosphere, 33(12), 2383-2393, 1996.

Ferentinos, G. and McManus, J.: Nearshore processes and shoreline development in St. Andrew's Bay, Scotland, UK, Special Publications in International Assessment of Sediment, 5, 161-174, 1981.

Ferrier, G. and Anderson, J. M.: The application of remote sensing data in the study of effluent disposal in the Tay estuary, Scot- land, International Journal of Remote Sensing, 17(18), 35413566, 1996.

Ferrier, G. and Anderson, J. M.: A multidisciplinary study of frontal systems in the Tay estuary, Scotland, Estuarine, Coastal and Shelf Science, 45, 317-336, 1997a.

Ferrier, G. and Anderson, J. M.: The application of remotely sensed data in the study of frontal systems in the Tay estuary, Scotland, UK, International Journal of Remote Sensing, 18(9), 2035-2065, 1997b.

Galois, R., Richard, P., and Fricourt, B.: Seasonal variations in suspended particulate matter in the Marennes-Oleron Bay, France, using lipids as biomarkers, Estuarine, Coastal and Shelf Science, 43, 335-357, 1996.

Gaskell, S. J. and Eglinton, G.: Rapid hydrogenation of sterols in a contemporary lacustrine sediment, Nature, 254, 209-211, 1975.

Gonzalez-Vila, F. J., del Rio, J. C., Mancha, A., Bautista, J. M., and Martin, F.: Origin and environmental significance of organic deposits in sediments, Fresenius Environmental Bulletin, 5, 161166, 1996.

Green, G., Skerratt, J. H., Leeming, R., and Nichols, P. D.: Hydrocarbon and coprostanol levels in seawater, sea-ice algae and sediments near Davis Station in eastern Antarctica, Marine Pollution Bulletin, 25(9-12), 293-302, 1992.

Green, G. and Nichols, P. D.: Hydrocarbons and sterols in marine sediments and soils at Davies Station, Antarctica: a survey for human-derived contaminants, Antarctic Science, 7(2), 137-144, 1995.

Grimault, J. O., Fernandez, P. Bayona, J. M., and Albaiges, J.: Assessment of faecal sterols and ketones as indicators of urban sewage inputs to coastal waters, Environmental Science and Technology, 24, 357-363, 1990.

Hammer, M. J.: Water and Wastewater Technology (second edition), John Wiley and Sons, New York, pp. 1-99, 322-332, 1986.

Hashim, M. H. A.: Tidal and seasonal chemical and mineralogical variation in the Tay estuary, $\mathrm{PhD}$ thesis, University of Dundee, 1985.

Hatcher, P. G. and McGillivary, P. A.: Sewage contamination in the New York Bight - coprostanol as a faecal indicator, Environmental Science and Technology, 13, 1225-1229, 1979.

Hubbard, F. H. and Hashim, M. H. A.: The nature and distribution of the suspended load of the middle Tay estuary, Proceedings of the Royal Society of Scotland, 92B, 359-371, 1987.

Huang, W. Y. and Meinschein, W. G.: Sterols as ecological indicators, Geochimica et Cosmochimica Acta, 43, 739-745, 1979.

Jeng, W. L. and Han, B. C.: Sedimentary coprostanol in Kaohsiung Harbour and the Tan-Shui estuary, Taiwan, Marine Pollution Bulletin, 28(8), 494-499, 1994.

Jeng, W. L., Wang, J., and Han, B. C.: Coprostanol distributions in marine sediments of southwestern Taiwan, Environmental Pollution, 94(1), 47-52, 1996.

Keith, S. M., Russ. M. A., Macfarlane, G. T., and Herbert, R. A.: The ecology and physiology of anaerobic bacteria isolated from Tay estuary sediments, Proceedings of the Royal Society of Edinburgh, 92B, 323-333, 1987.

Kelly, A. G.: Accumulation and persistence of chlorobiphenyls, organochlorine pesticides and faecal sterols at the Garroch Head sewage sludge disposal site, Firth of Clyde, Environmental Pollution, 88, 207-217, 1995.

Lajat, M., Saliot, A., and Schimmelman, A.: Free and bound lipids 
in recent (1835 - 1987) sediments from Santa Barbara Basin, Organic Geochemistry, 16(4-6), 793-803, 1990.

Laurelliard, J. and Saliot, A.: Biomarkers in organic matter produced in estuaries: a case study of the Krka estuary (Adriatic Sea) using the sterol marker series, Marine Chemistry, 413(1-4), 247-261, 1993.

LeBlanc, L. A., Latimer, J. S., Ellis, J. T., and Quinn, J. G.: The geochemistry of coprostanol in waters and surface sediments from Narragansett Bay, Estuarine, Coastal and Shelf Science, 34, 439458, 1992.

Leeming, R. and Nichols, P. D.: Determination of the sources and distribution of sewage and pulp-fibre derived pollution in the Derwent estuary, Tasmania, using sterol biomarkers, Marine Freshwater Resources, 49, 7-17, 1998.

Li, W., Dagaut, J., and Saliot, A.: The application of sterol biomarkers to the study of the sources of particulate organic matter in the Solo River system and Serayu River, Java, Indonesia, Biogeochemistry, 31, 139-154, 1995.

Mackenzie, A. S., Brassell, S. C., Eglinton, G., and Maxwell, J. R.: Chemical fossils: the geological fate of sterols, Science, 217 , 419-504, 1982.

McCalley, D. V., Cooke, M., and Nickless, G.: Coprostanol in Severn estuary sediments, Bulletin of Environmental Contamination and Toxicology, 25, 374-381, 1981.

McManus, J.: Data from the tidal cycle measuring stations in the Tay estuary, 1972-1982, Tay Estuary Research Centre Report no. 8, University of Dundee, 1984.

McManus, J.: Sediment transport patterns in the Tay estuary, in: Third International Symposium on River Sedimentation, edited by: Wang, S. Y., Shen, H. W., and Ding, L. Z., School of Engineering, University of Mississippi, 517-524, 1986.

Marty, Y., Quemeneur, M., Aminot, A., and le Corre, P.: Laboratory study on degradation of fatty acid and sterols from urban wastes in seawater, Water Resources, 30(5), 1127-1136, 1996.

Marvin, C., Coakley, J., Mayer, T., Brown, M., and Thiessen, L.: Application of faecal sterol ratios in sediments and effluents as source tracers, Water Quality Research Journal of Canada, 36(4), 781-792, 2001.

Mudge, S. M. and Bebbiano, M. J.: Sewage contamination following an accidental spillage in the Ria Formosa, Portugal, Marine Pollution Bulletin, 34(3), 163-170, 1997.

Mudge, S. M. and Norris, L. E.: Lipid biomarkers in the Conwy estuary (North Wales, U.K.): a comparison between fatty alcohols and sterols, Marine Chemistry, 57, 61-84, 1997.

Mudge, S. M., Bebbiano, M. J. A. F., East, J. A., and Barreira, L. A.: Sterols in the Ria Formosa lagoon, Portugal, Water Research, 33(4), 1038-1048, 1999.

Nichols, P. D., Leeming, R., Rayner, M. S., and Latham, V.: Use of capillary gas chromatography for measuring faecal sterol derived sterols: application to stormwater, the sea surface microlayer, beach greases, regional studies and distinguishing algal blooms and human and non-human sources of sewage pollution, Journal of Chromatography, 733A, 469-509, 1996.

Nishimura, M.: Origin of stanols in young lacustrine sediments, Nature, 270, 711-712, 1977.

O'Leary, T., Leeming, R., Nichols, P. D., and Volkman, J. K.: Assessment of the sources, transport and fate of sewage derived organic matter in Port Phillip Bay, Australia, using the signature lipid, coprostanol, Marine and Freshwater Research, 50(6), 547-
$556,1999$.

Owen, R. E. and Balls, P. W.: Dissolved trace metals in the Tay estuary, Estuarine, Coastal and Shelf Science, 44, 421-434, 1997.

Patton, D.: Determination of domestic wastewater effluent in the Firth of Tay: A biomarker approach, $\mathrm{PhD}$ Thesis, University of Dundee, 1998.

Patton, D. and Reeves A. D.: Measuring change in sterol input to estuarine sediments, Physics and Chemistry of the Earth, 26(9), 753-757, 2001.

Quemeneur, M. and Marty, Y.: Fatty acids and sterols in domestic wastewaters, Water Resources, 28(5), 1217-1226, 1994.

Reeves, A. D. and Duck R. W.: Density fronts: Sieves in the estuarine sediment transfer system?, Physics and Chemistry of the Earth, 26(1), 89-92, 2001.

Readman, J. W., Mantoura, R. F. C., Llewellyn, C. A., Preston, M R., and Reeves, A. D.: The use of pollutant and biogenic markers as source discriminants of inputs to estuarine sediments, International Journal of Analytical Chemistry, 27, 29-54, 1986.

Saliot, A. and Tusseau, D.: Sterols in interstitial waters of marine sediments, Organic Geochemistry, 7(1), 53-59, 1984.

Saliot, A. Laurelliard, J., Scribe, P., and Sicre, M. A.: Evolutionary trends in the lipid biomarker approach for investigating the biogeochemistry of organic matter in the marine environment, Marine Chemistry, 36, 233-248, 1991.

Saliot, A., Parrish, C. C., Sadouni, N., Bouloubassi, L., Fillaux J., and Cauwet, G.: Transport and fate of Danube Delta terrestrial organic matter in the Northwest Black Sea mixing zone, Marine Chemistry, 79(3-4), 243-259, 2002.

Sherblom, P. M., Henry, M. S., and Kelly, D.: Questions remain in the use of coprostanol and epicoprostanol as domestic waste markers: examples from coastal Florida, ACS Symposium Series, 671, 320-331, 1997.

Sherwin, M. R., van Vleet, E. S., Fossato, V. U., and Dolci, F. Coprostanol in lagoonal sediments and mussels of Venice, Italy, Marine Pollution Bulletin, 26(9), 501-507, 1993.

Sicre, M. A., Tian, R. C., and Saliot, A.: Distribution of sterols in suspended particles in the Chang-Jiang estuary and adjacent east China Sea, Organic Geochemistry, 21(1), 1-10, 1994.

Sikes, A. L.: Techniques of isotope and organic geochemistry analysis and sampling, website: http//www.erin.gov.au/sea/ workshop/geoscience/sikes.html, 1996.

Simpson, J. H. and Turrell, W. R.: Convergent fronts in the circulation of tidal estuaries, in: Estuarine Variability, edited by: Wolfe. D. A., Academic Press Inc., London, 139-152, 1986.

Takada, H., Farrington, J. W., Bothner, M. H., Johnson, C., and Tripp, B. W.: Transport of sludge-derived organic pollutants to deep sea sediments at Deep Water Dump Site 106, Environmental Science and Technology, 28, 1062-1072, 1994.

Tian, R. C., Sicre, M. A., and Saliot, A.: Aspects of the geochemistry of sedimentary sterols in the Chang Jiang estuary, Organic Geochemistry, 18(6), 843-850, 1992.

Thornton, S. F. and McManus, J.: Applications of organic carbon and nitrogen stable isotope and $\mathrm{C} / \mathrm{N}$ ratios as source indicators of organic matter provenance in estuarine systems: evidence from the Tay estuary, Scotland, Estuarine, Coastal and Shelf Science, 38, 219-133, 1994.

Venkatesan, M. I. and Kaplan, I. R.: Sedimentary coprostanol as an index of sewage addition in Santa Monica Basin, southern California, Environmental Science and Technology, 24(2), 208- 
214, 1990.

Venkatesan, M. I., Ruth, E., Rao, P. S., Nath, B. N., Rao, B. R.: Hydrothermal petroleum in the sediments of the Andaman Backarc Basin, Indian Ocean, Applied Geochemistry, 18(6), 845-861, 2003.

Volkman, J. K.: A review of sterol markers for marine and terriginous organic matter, Organic Geochemistry, 9(2), 83-99, 1986.

Walker, C. H., Hopkin, S. P., Sibley, R. M., and Peakall, D. B.: Principles of Ecotoxicology, Taylor and Francis,, London, 1996.

Walker, R., Wun, C. K., and Litsky, W.: Coprostanol as an indicator of faecal pollution, CRC Critical Reviews in Environmental Control, 12(2), 91-112, 1982.
Weir, D. J. and McManus, J.: The role of wind in generating turbidity maxima in the Tay estuary, Continental Shelf Research, 7(11-12), 1315-1318, 1987.

Wewetzer, S. F. K.: Bedforms and sediment transport in the middle Tay estuary, Scotland: a side scan sonar investigations, $\mathrm{PhD}$ thesis, University of St. Andrews, 1998.

Writer, J. H., Leenheer, J. A., Barber, L. B., Amy, G. L., and Chapra, S. C.: Sewage contamination in the upper Mississippi River as measured by the faecal sterol, coprostanol, Water Research, 29(6), 1427-1436, 1995. 